研究課題別 評価書

1. 研究課題名

プローブラベリングによるタンパク質間相互作用解析

2. 氏名

王子田 彰夫

3. 研究のねらい

細胞内の多くのタンパク質は、複数のタンパク質からなるタンパク質複合体を構成して機能 を発現している。本研究では、タンパク質複合体の構成と機能を解析するため新しいタンパク 質ラベル化法の開発を目指す。このタンパク質ラベル化技術を用いて様々な機能性分子プ ローブの標的タンパク質への特異的にラベル化を実現し、タンパク質複合体の蛍光可視化 やタンパク質間相互作用変化の検出を可能とする基盤技術の確立を目指す。

4. 研究成果

機能性プローブによるタンパク質のラベル化は、タンパク質の機能解析に極めて有用な手 法である。このプローブラベル化によるタンパク質機能解析を行うためには、小分子プローブ を特定のタンパク質の特定部位に選択的に標識する技術が必要となる。タンパク質に導入し た短いペプチドタグと、これと特異的に強く相互作用する小分子プローブの組み合わせを利 用したタグ・プローブペアは、タンパク質の特異的ラベル化を可能とする分子ツールとして有 用である。本さきがけ研究では、このタグ・プローブペアによるタンパク質ラベル化技術を応 用して、様々な小分子プローブをタグ導入タンパク質へと共有結合ラベル化できる手法(リア クティブタグシステム)の開発を行った(図1)。本研究では、このタグ・プローブペアから構成 されるタンパク質ラベル化法を、細胞系におけるタンパク質間相互作用解析へと応用するこ とを目標として研究を展開した。
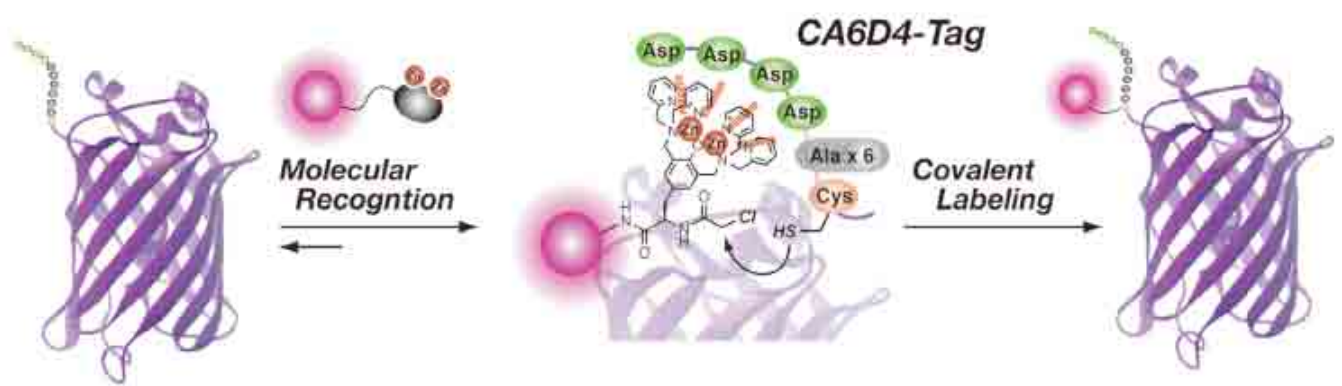

図1.リアクティブタグ法によるタグ導入タンパク質の特異的共有結合ラベル化

本研究の開始に先駆けて我々は、チロシンを基本骨格とする二核亜鉛錯体Zn(II)-DpaTyr が、連続するアスパラギン酸4連続配列 (DDDD; D4 タグ) と 1: 1 のコンプレックスを形成して 強く相互作用できる基礎的な知見を見出した(図2)。我々は、タグとZn(II)-DpaTyr亜鉛錯体 間のより強い相互作用を得るために、D4 タグを二つ連続させた配列(DDDDGDDDD)を有する タンパク質とZn(II)-DpaTyrを二つ連結した亜鉛錯体ダイマーとの親和性は $\mathrm{K}_{\mathrm{d}}$ にして $55 \mathrm{nMl}$ 達し、マルチバレントな相互作用により非常に強いタグ・プローブ間の相互作用が達成できる ことを明らかとした。本研究において我々は、このタグ/プローブペアを細胞表層に発現する GPCRタンパク質のバイオイメージングへと応用した。すなわち、細胞外領域にD4 タグを導入 したアセチルコリン受容体(AChR)をCHO細胞に発現させ、亜鉛錯体型プローブ 1-4Zn(II)を持 いてラベル化する事により、細胞表層に発現している受容体を蛍光可視化することに成功し た(図2)。 


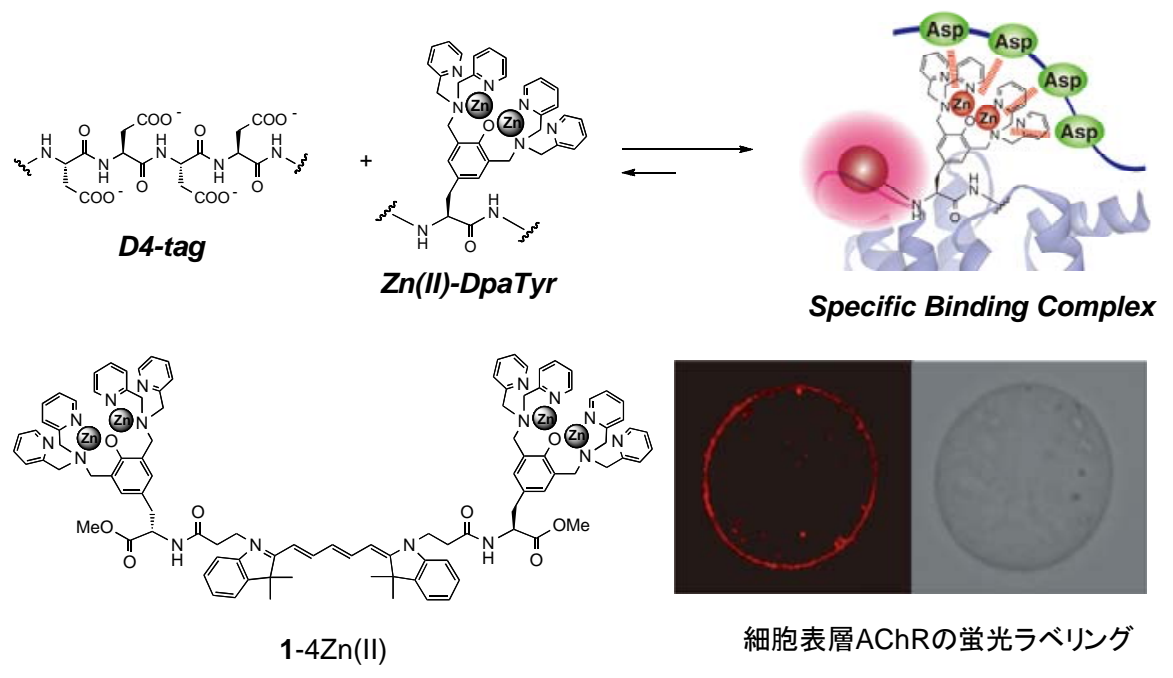

図2.D4 タグと Zn(II)-DpaTyr の特異的相互作用

しかしながら、このラベル化法では、タグとプローブは可逆な金属一配位子相互作用で結 合しているのみであり、蛍光標識はしだいに減弱し、またラベル化後の FACS やブロッティン グ解析などは困難となりツールとしての応用性に限りがある。本研究では、この問題を解決 するために、タグと小分子プローブとが非加逆的な共有結合により連結される新しい手法(リ アクティブタグシステム)の開発を行った(図1)。このリアクティブタグシステムでは、タグとプ ローブとが分子認識により複合体を形成した状態において、両者の近接および配向効果に より特異的な共有結合形成反応が起こる。このような共有結合反応を起こす組み合わせとし て、タグとしてはシステインを有するアスパラギン酸4連続配列、プローブは $\alpha$ ークロロアセチ ル基を有する $\mathrm{Zn}$ (II)-DpaTyr を新たにデザインした(図3)。アスパラギン酸4連続配列とシス テインとの間に複数個のアラニンを含むぺプチドタグとプローブ 2-2Zn(II)との共有結合反応 を検討したところ、アラニンが6個のペプチドタグ(CAAAAAADDDD;CA6D4 タグ)が非常に早 い反応速度で特異的にラベル化されることが明らかとなった。その反応の初速度は、タグと プローブ間の分子間相互作用がない場合と比較すると約 1,500 倍加速されていた(図3)。ア ラニンの数が異なるペプチドでは、CA6D4 タグに見られる大きな反応速度は観測されず、 CA6D4 タグの特異的な高反応性は興味ある現象である。次に CA6D4 タグを導入した EGFP タンパク質を用いてラベル化反応についての検討を行った。MALDI-TOF マスにより、CA6D4 タグを有する EGFP タンパク質のラベル化反応を追跡すると、反応は非常に迅速であり開始 後15分でほぼ定量的なラベル化が起こる事が明らかとなった(図3)。また、フリーのシステ インを有する複数のタンパク質との混合系において反応を行ったところ、反応は CA6D4 タグ を有するEGFPにのみ選択的進行している事が明らかとなった。さらに我々は、大腸菌ライセ 一ト中において過剩発現させたタグ導入 MBP プロテインに対しても、ラベル化反応が選択的 に進行する事を確認した。この様な人エのタグ・プローブペア間の非酵素的かつ特異的な共 有結合ラベル化法はこれまでに例がなく、我々はこれを「リアクティブタグシステム」と名付け た。 
a)

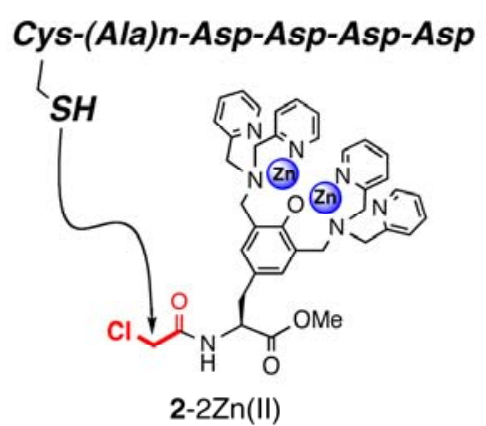

b)

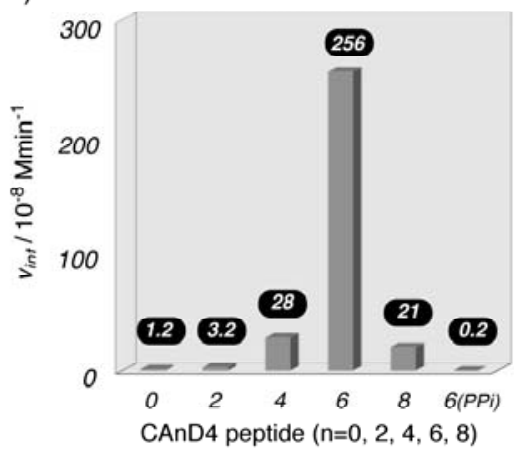

c)

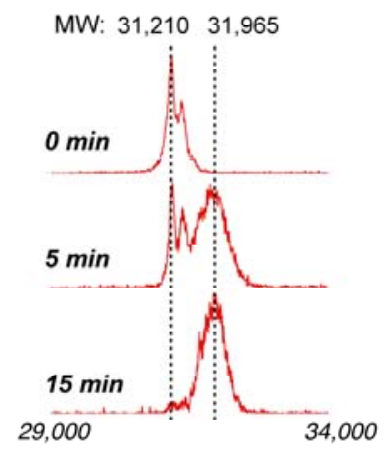

図3. a) リアクティブタグシステムにおける共有結合形成反応 b) 各タグペプチドの反応初速度の 比較 c) CA6D4 タグを導入した EGFP タンパク質のラベル化反応の追跡(MALDI-TOF マス)

次に「リアクティブタグシステム」を細胞表層に発現させた GPCR 受容体の共有結合ラベル 化へと応用した。GPCR としてまず、ブラジキン受容体(B2R)を選択し、細胞外領域に 16 残基 のタグ配列(CAAAAAADDDDGDDDD;CA6Dx2 タグ)を有する形で HEK293 細胞に発現させた。 プローブとしては、 $\alpha$ 一クロロアセチル基(反応部位)とローダミン (蛍光団)を有する 4 核亜鉛 錯体 3-4Zn(II)を設計した(図3)。当初、両者の反応は進行しなかったが、細胞を TCEP など の穏やかな還元剂で処理することにより、B2R 受容体の共有結合ラベル化反応が効よく進行 することが共焦点レーザ一顕微鏡を用いた蛍光イメージング実験から明らかとなった(図3)。 この原因としては、タグ上のシステイン残基が細胞外の酸化的雾囲気化で酸化され、ジスル フィドを形成、不活性化されているためであると考えられる。ラベル化反応の定量的解析を行 ったところ、反応は細胞表層においても30分程度で飽和に達することが明らかとなった。通 常の蛍光によりバイオイメージングを行うのであれば、ラベル化はわずか 10 分程度であった。 ラベル化のコントロール実験としてタグのない B2R 受容体や $\alpha$ 一クロロアセチル基を持たない プローブを用いた場合には、ラベル化反応は進行しない。これらのニつのコントロール実験 の結果および上記の還元剂処理の必要性から、ラベル化反応は受容体に導入したタグ上の システイン残基とプローブの $\alpha$ 一クロロアセチル基間で進行していることが強く示唆される。ま た、GPCR としてアセチルコリン受容体(AChR)を用いても、ラベル化は HEK293 細胞表層にお いて同様に効率よく進行することを確認した。本手法のラベル化技術としての汎用性を示す 結果である。

a)

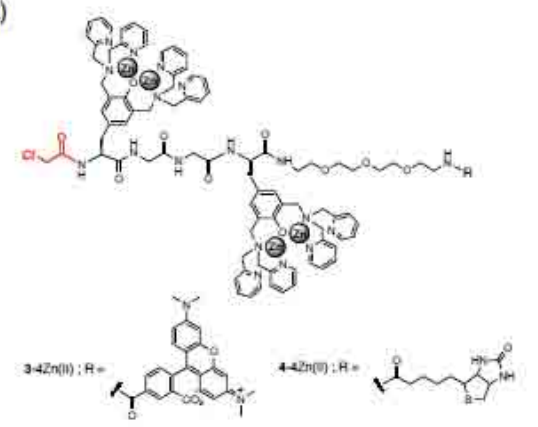

b)

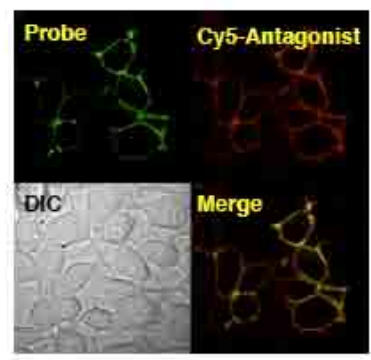

c)

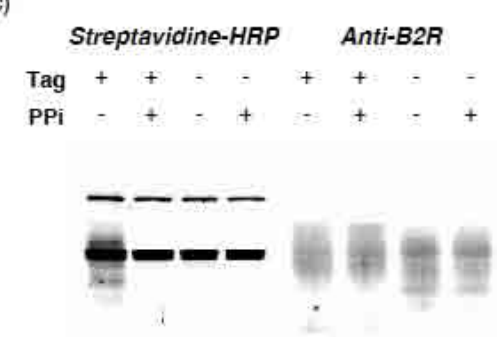

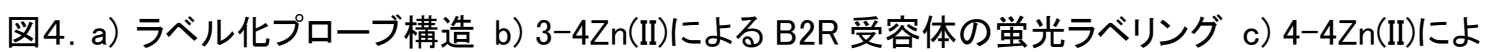
る B2R 受容体ラベル化後のブロッテイング解析

本ラベル化反応を用いることにより、様々な機能性プローブを GPCR 上に導入する事が可 能である。例えば、異なる色の蛍光色素を有するプローブを用いてラベル化を行う事により、 様々な蛍光波長での GPCR のイメージングが可能であった。また、ビオチン型プロ 4-4Zn(II) 
を用いる事により、GPCR 上にビオチンを導入することが可能であった。ビオチンの導入は、 細胞破砕後のブロッティング解析により確認された(図4)。このようなラベル化後のブロッティ ング解析は、付加逆な共有結合ラベル化においてはじめて可能であり、先に開発した分子間 相互作用によるラベル化法ではなし得ない事である。我々はさらに、ラベル化を行った膜受 容体の細胞内動態解析として、アゴニスト刺激による受容体インターナリゼーションの蛍光イ メージングを行った(図5)。B2RおよびAChRをそれぞれ対応するアゴニストで刺激を行うと、 蛍光ラベル化された受容体を含むエンドソーム顆粒が時間の経過に伴って細胞内に移行、 蓄積する様子をとらえることに成功した。この結果は、標識された受容体の機能が阻害され ておらず、アゴニスト刺激に対する応答能を維持している事を示す。また、 $\mathrm{pH}$ 感受性の蛍光 プローブをラベル化する事により、エンドソーム内の酸性化を蛍光により検出することにも成 功し、本手法がタンパク質に連関した様々な細胞機能解析へと応用可能であることを実証し た。

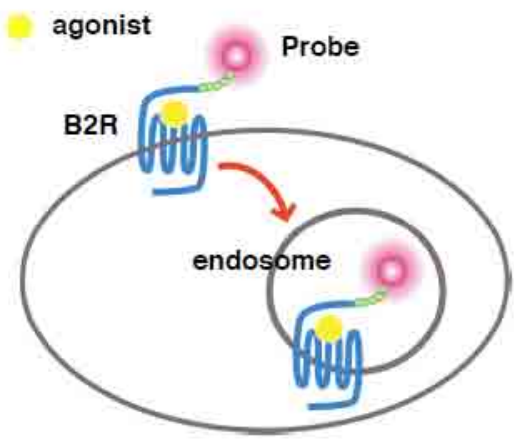

a)

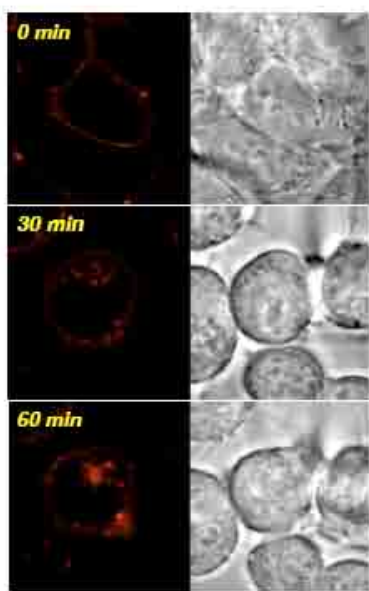

b)

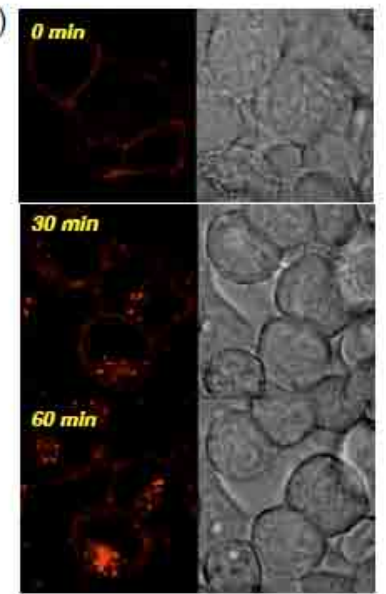

図5. 3-4Zn(II)でラベル化された B2R 受容体(a)および AChR 受容体(b)のアゴニスト刺激に伴うイ ンターナリゼーションの蛍光可視化

5. 自己評価

標的タンパク質の特異的ラベル化を目指した「リアクティブタグシステム」として、1)非常に 早い速度でラベル反応を起こすタグ/プローブのペアを見出した。2) 見い出したタグ/プロ 一ブペアを細胞表層に発現する GPCR 受容体タンパク質に対して適用し、特異的なラベル化 に成功した。3)タンパク質機能の解析例として、GPCR 受容体のインターナリゼーションの可 視化などへの応用に成功した。以上の結果から、細胞表層タンパク質のラベル化および機 能解析の確かな技術として「リアクティブタグシステム」を確立できたと考えている。

6. 研究総括の見解

(Asp)4 あるいはこれを倍長した亜鉛錯体を SH 基と共有結合可能なタグ認識ラベル化分子 を作製し、具体的応用例としてブラディキニン受容体をラベル化し多色イメージングに成功し ている。まだ細胞表層膜タンパク質だけであり、しかも細胞外からのラベル化など限定的であ る。しかし、 $\mathrm{pH}$ 感受性色素を用いてエンドソーム内の酸性度をイメージング化している点は興 味深い。細胞研究のための合成小分子ラベル法を着実に進めていると評価出来る。より簡 便な導入法と合成法の開発が望まれる。 
7. 研究成果リスト

A. さきがけ個人研究者が主導で得られた成果

(1) 論文 (原著論文) 発表 論文 (国際)

-K. HONDA, S. FUJISHIMA, A. OJIDA, I. HAMACHI, Pyrene Excimer Based Dual-Emission Detection of a Oligo-Aspartate Tag Fused Protein Using Zn(II)-DpaTyr Probe, ChemBioChem, 8, 1370-1372 (2007).

-H. NONAKA, S. TSUKIJI, A. OJIDA, I. HAMACHI, Non-enzymatic Covalent Protein Labeling Using a Reactive Tag, J. Am. Chem. Soc., 129, 15777-15779 (2007).

-S. UCHINOMIYA, H. NONAKA, S. FUJISHIMA, S. TSUKIJI, A. OJIDA, I. HAMACHI, Site-Specific Covalent Labeling of His-tag Fused Proteins with a Reactive Ni(II)-NTA Probe, Chem. Commun., 5880-5882 (2009).

- A. OJIDA, S. FUJISHIMA, K. HONDA, H. NONAKA, S. UCHINOMIYA, I. HAMACHI, Binuclear Ni(II)-DpaTyr Complex as a High Affinity Probe for an Oligo-Aspartate Tag Tethered to Proteins, Chemistry-An Asian Journal, in press.

-H. NONAKA, S. FUJISHMA, S. UCHINOMIYA, A. OJIDA, I. HAMACHI, Selective Covalent Labeling of Tag-Fused Proteins with a Small Molecule Probe for Functional Analysis of Cell Surface GPCR Proteins, J. Am. Chem. Soc, in press.

(2) 特許出願

研究期間累積件数: 0件

(3) 学会発表

学会発表（国内）

·野中洋、藤島祥平、本田圭、王子田彰夫、浜地 格、リアクティブタグシステムによる新規タ

ンパク質ラベル化法の開発、日本化学会 第 87 春季年会(2007.3.25)

·王子田彰夫、「タグー小分子プローブ」ペアによるタンパク質の特異的認識と可視化、日本 薬学会 第127年会 (2007.3.30)

·王子田彰夫、野中 洋、藤島 祥平、内之宮 祥平、浜地 格、D4 タグに対するリアクティブ タグシステムの開発、日本化学会第89春季年会 (2009.3.28)

·内之宮 祥平、野中 洋、藤島祥平、王子田彰夫、浜地 格、His タグに対するリアクティブタ グシステムの開発、日本化学会第89春季年会 (2009.3.28)

·野中 洋、内之宮祥平、藤島 祥平、王子田 彰夫、浜地 格、D4 リアクティブタグシステム による細胞表層受容体の機能解析、第 24 回生体機能関連化学シンポジウム (2009. 9. 14)

\section{(4) 招待講演}

招待講演 (国内)

·王子田彰夫、生体機能を探る金属錯体蛍光プローブ、第一回瀬戸薬セミナー（2007.12. 05, 松山大学)

·王子田彰夫、バイオイメージングのための新しいタンパク質ラベル化技術の開発、生理学 
研究所 公開セミナー (2008.11.25、岡崎)

- 王子田彰夫、生体機能解析に使いたくなる蛍光プローブの開発、有機合成化学講演会 (2009. 5.22、福岡)

·王子田彰夫、生体機能を解き明かすツールとしての小分子プローブの開発、生体関連化学 若手の会 (2009. 7.13、京都) 